\title{
Structural Adaptations Associated with Osmotic Stress of The Salt Gland in Birds
}

\author{
Zeinab M. El- Gohary, Fawkeia I. El-Sayad, Hanaa A. Hassan and Aya M. Hamoda \\ Zoology Dept., Faculty of Science, Mansoura University, Egypt
}

\begin{abstract}
:
Introduction: When the drinking water of many species of ducks is changed from freshwater to saline, their salt glands hypertrophy and the principal cells showed numerous lateral cell evaginations and abundant mitochondria, enhancing their capacity to excrete salt.

Aim of the work:The purpose of this investigation was to demonstrate and evaluate the anatomical, histological, and ultrastructural adaptations of the salt gland of the domestic female ducks associated with high salt osmotic stress.
\end{abstract}

\section{Material and methods:}

The present study was carried out on two groups of female domestic ducks and one group of wild ducks. Where as one group of domestic ducks was exposed to osmotic stress; imposed by replacing drinking tap water with $1 \%$ sodium chloride solution for two consecutive weeks. Morphometric measurements as well as histological and ultrastructural aspects of the salt glands were considered.

Results: The investigation revealed that the weight and size of the salt glands of the saltstressed ducks were markedly heavier and larger in comparison to those of the control and wild ducks. The number and the diameter of secretory lobules as well as the length of secretory tubules of the salt-stressed group were greater compared to the control ones. The degree of the proliferation and differentiation of the peripheral cells was distinctly greater for the salt-stressed than the control and wild ducks. The basal and lateral surfaces of the fully specialized secretory cell type in the salt-stressed and wild birds were obviously amplified and in many cases the folds of adjacent cells meshed with one another forming an elaborate complex of extracellular spaces and intracellular compartments. The cytoplasm of the fully specialized principal cells displayed abundant endoplasmic reticulum, numerous well developed mitochondria and deeply well developed basal foldings which increase the absorptive surface.

Conclusion: The recorded peculiar features of the salt glands of the salt-stressed birds may be presented as an adaptive features to satisfy its special demands to eliminate the remarkable increased levels of sodium chloride load effectively.

Key words: Histology, Supraorbital salt gland, Adaptations, Osmotic stress, Ultrastructure

\section{Introduction:}

Active nasal salt glands have been reported in several avian orders (Spheniciformes, Precelariformes, Charadriformes, Pelecaniformes, Anseriformes, Phoenicopteriformes), in which post-renal transport mechanisms are used to conserve urinary water and to recycle excess $\mathrm{NaCl}$ to the nasal salt glands $(1,2)$. The salt glands are not restricted to birds that live in saline or maritime habitats, but are also present in some terrestrial avian species $(3,4)$.

A typical salt gland is a bilateral paired crescent-shaped organ, composed of separate medial and lateral segments (5). Each segment consists of several longitudinal lobules composed of secretory tubules radiating from central canals. These, in turn, form secondary and primary ducts running toward the nasal cavity and discharging the hypertonic fluid through the nares (6). There are no evident differences in tubule length or in types and distribution of secretory cells within the medial and lateral segments even though they have different embryonic origins (7).

Since the avian salt gland provides an extra-renal pathway for the maintaince of homeostasis because bird kidneys are generally incapable of excreting all electrolytes (8), many species of ducks be able to switch seasonally between 
freshwater and saline habitats. In some avian and reptelian species, the salt gland exhibits reversible phenotypic plasticity. The variation in the plastic response of bird salt glands may be related to the ecology, and probably, to the ecological flexibility of species $(9,10)$.

The adaptive hyperplasia is induced when duckling become osmotically stressed for the first time (11). Cell proliferation, especially of the peripheral cells that line the blind ends of the secretory tubules, leads to tubule elongation and optimizes the salt-excretory capacity of the organs $(11,12)$.

Several studies had demonstrated changes in mass and function of the salt gland in birds exposed to hypertonic salt solutions both in the field and laboratory $(13,14,15)$. When the ducks and/ or geese are initially exposed to osmotic stress, the nasal glands proliferate and show an increase in the number of secretory cells (hyperplasia) and reorganization of existing ones to reach full differentiation within a few days $(4,16)$.

The ultrastructure investigation of the salt glands of the roadrunner injected with salt and of quail drinking $200 \mathrm{mM} \mathrm{NaCl}$ resulted in the presence of numerous lateral cell evaginations and abundant mitochondria in the principal cell types (17).

\section{Aim of the work:}

The present study aimed to demonstrate, evaluate and compare the different structural adaptations of the salt glands of the domestic non-marine female ducks (Anas platyrhyncha) associated with osmotic stress. The migratory wild northern shovelers ducks (Anas clypeata) inhabiting brackish water in the Lake Manzala were considered in this investigation to be compared with those experimentally osmotic-stressed domestic ducks.

\section{Material and Methods:}

\section{1- Experimental animals}

The experimental animals included two different avian species which inhabit different ecological niches; domestic ducks (Anas platyrhyncha) and the wild migratory northern shoveler (Anas clypeata) ducks. The domestic ducks inhabit lakes, streams and nearby grassland and farm crops (18). On the other hand, the wild migratory ducks are particularly fond of fresh and brackish waters. In winter, they look for the mildness of maritime coasts (19). In Egypt they winter in the area of Lake Manzala, thereby they might ingest large amount of salty water. Both studied species were belong to the family Anatidae or dabbling ducks.

The domestic ducks were bought from a local duck farm while the wild migratory ducks were hunted from the Lake Manzala area and transported immediately to the laboratory for subsequent experimental investigation. The domestic ducks were housed in special avian farm under a cycle of $12 \mathrm{~h}$ light $-12 \mathrm{~h}$ dark and fed commercial duck grower food with drinking water ad libitum for a further three days before they were used for the experiments. The different studied groups including:

- Control female domestic ducks (Anas

$$
\text { platyrhyncha) (9). }
$$

- Salt-stressed female domestic ducks (Anas platyrhyncha) (9).

- Wild female migratory ducks

$$
\text { (Anas clypeata) (9). }
$$

Each group included nine healthy adult female birds. The treated group of the domestic ducks (the salt-stressed group) was given $1 \% \mathrm{NaCl}$ solution to drink for two consecutive weeks. While the control ducks were maintained exclusively on tap water for the same period.

\section{1- Microscopic Investigation} 1- Histological preparation

Since the structure of the medial and lateral segments of the salt glands of the avian species are identical (7), only the medial segments were considered in the present study. At the end of the experiment, all the studied birds were weighed separately then sacrificed by a sharp knife, after which they were dissected to remove out the right and left salt glands from the eye socket after pulling out the eye balls. The glands were immediately cleaned by filter paper and weighed separately. The gross anatomy of the medial segments of the salt glands of the different studied groups were examined and photographed. 
For the histological study, only the left medial segments of the salt glands were used. The tissue samples were immersed in $10 \%$ neutral formalin for 48 hours for fixation, after which the fixed samples washed with tap water and dehydrated with ascending grades of ethanol $(50 \%$ up to $100 \%$ ). Dehydration was followed by clearing the samples with xylol, then mounted in paraffin wax. Sections (5-7 $\mu \mathrm{m})$ were stained with Harris haematoxylin and eosin (20). Histological sections were examined by a light microscope and photographed.

\section{2- Morphometeric investigation}

The stained histological sections were used to enumerate (count) the number of secretory lobules per each microscopic field at magnification X40 for ten different areas and the mean number was computed. Also, the diameters of the secretory lobules as well as the length of the secretory tubules for the studied species were measured in 4 slides for each gland using an eye-piece ocular micrometer for at least five lobules and seven tubules for each slide.

\section{3- Ultrastructural studies}

The left medial segments of the salt glands were also used for ultrastructural study. Small pieces appropriate $\left(1 \mathrm{~mm}^{3}\right)$ of the gland tissues of the studied groups were excised and fixed in $2.5 \%$ glutaraldhyde in $0.1 \mathrm{M}$ sodium cacodylate buffer at $\mathrm{pH} 7.2$ (for 3 hours), the tissue was post-fixed in $1 \%$ buffered osmium tetroxide for 1 hour at $4^{\circ} \mathrm{C}$. The fixed tissue was dehydrated in ascending grades of ethanol, cleared in propylene oxide, then embedded in epon (21). Ultra- thin sections $(60-90 \mathrm{~nm})$ were stained with uranyl acetate and lead citrate $(22,23)$ then examined with JEOL transmission electron microscope operating at 60 or 80 $\mathrm{KV}$. The present ultrastructure studies were done in the electron microscope unit of Faculty of Science, University of Ain Shams, Cairo.

\section{I11- Statistical Analysis}

Statistical evaluation of the present data was carried out using one ways Anova test whereas the level of significance was estimated taking the probability $(\mathrm{p}<0.05)$ as a minimal requirement for significance.
All the investigated parameters were presented as means \pm standard error.

Results

\section{1- Salt gland weight}

The absolute weights of the right $(\mathbf{0 . 5 7} \pm$ $\mathbf{0 . 0 4 g})$ and left $(\mathbf{0 . 5 7} \pm \mathbf{0 . 0 3 g})$ medial segments of the salt glands of the saltstressed ducks were significantly $(\mathrm{P}<0.001)$ heavier compared to the corresponding values of the right $(\mathbf{0 . 3 9 \pm}$ $0.01 \mathrm{~g}),(0.14 \pm 0.02 \mathrm{~g})$ and left $(0.43 \pm$ $0.01 \mathrm{~g}),(0.15 \pm 0.02 \mathrm{~g})$ medial segments of the control and wild ducks respectively as shown in Table (1). In addition, the relative weights of the medial segments followed the same pattern as those of the absolute weights ; with the salt-stressed ducks had the heaviest followed by the control then the wild ducks which showed the lightest relative weight.

\section{2- Gross anatomy}

The gross anatomy investigation of the salt glands showed that all the examined birds had bilateral paired crescent-shaped lobular, compound, branched, tubular, salt-secreting glands located within the socket of the orbit. The salt gland was composed of tubes or lobes, giving it a characteristic surface structure. Each gland composed of separate medial and lateral segments, however, in the present study only the medial segments of the salt glands were considered.

The colour of the medial segments of the salt-stressed as well as the wild migratory ducks seemed relatively dark reddish when compared to that of the control ones which was relatively pale in colour. The most striking change in duck salt glands subsequent to salt manipulation was the increase in gland size. The size of the medial segment of the salt-stressed ducks was markedly larger in comparison with the control and wild ones Fig. (1).

\section{3-Morphometeric studies}

The data considering the number and diameter of the secretory lobules as well as the length of the secretory tubules of the salt glands of the different studied species were recorded in Table (1) and illustrated in Figs. (2-4 ). The data showed that the salt-stressed ducks had (4士0.3) significantly $(\mathrm{P}<0.01)$ greater numbers of secretory lobules than the control ones 
$(\mathbf{3} \pm \mathbf{0 . 3})$ and the same number as those of the wild ones $(\mathbf{4} \pm \mathbf{0 . 3})$.

In addition, the salt-stressed ducks had the largest $(\mathbf{1 1 6 0 \pm 5 6} \boldsymbol{\mu m})$ diameter of the secretory lobules, followed by that of the wild migratory ducks $(\mathbf{9 1 3} \pm \mathbf{5 8} \boldsymbol{\mu m})$ then the control ducks which had the smallest $(\mathbf{7 7 2} \pm \mathbf{5 5} \boldsymbol{\mu m})$ diameter.

Moreover, the secretory tubules of the salt-stressed ducks $(\mathbf{1 5 7} \pm 9 \mu \mathrm{m})$ was longer than the control $(\mathbf{1 4 3} \pm \mathbf{9 \mu \mathrm { m }})$ and wild migratory ducks $(\mathbf{1 5 5} \pm \mathbf{1 5} \boldsymbol{\mu m})$ respectively. However, there was no significant difference for all the studied groups.

\section{4- Histological organization}

Histological investigation of the salt gland of the selected groups revealed that the medial segment consisted of numerous longitudinal secretory lobules which separated by interlobular connective tissue. The secretory lobules composed of branching secretory tubules radiating from central canals Fig.( 5) whereas the latter contained cellular debris in both the saltstressed and wild migratory ducks as presented in Fig. (6). In the periphery of the lobule, the tubules were run parallel to each other, separated by very delicate connective tissue membranes and blood capillaries. The tubules were closely packed together in both salt-stressed and wild ducks in comparison with control ducks see Fig. ( 7 ). The secretory tubules branched 4-6 times forming different "generations" or "orders" of tubules. The degree of the hypertrophy of the branched secretory tubules was greater in saltstressed than both control and wild ducks Fig. ( 8). Close to the central canal, where the gland tubules had not yet branched extensively, the tubules were round in transverse section Fig. (9) and separated by highly vascularised connective tissue in salt-stressed and wild ducks compared to control ones Fig. (10). The secretory tubules formed a honeycomb-like pattern at the peripheral parts of a lobule Fig.(11). The cytoplasm of the cells had a lamellate or striate appearance. The striation was not limited to a striated border, but extends through the cells from the lumen to the periphery, where the cells were in contact with blood capillaries Fig.(12).
The secretory tubules were lined by simple cuboidal-columnar epithelium. Two types of cells comprised the secretory epithelium: peripheral cells and principle secretory cells Fig. (13). The peripheral cells lied at the blind ends of the secretory tubules and were active in mitosis. They showed cellular proliferation, the degree of which was distinctly greater in saltstressed ducks than both the wild migratory and the control ducks Fig. (14). The remainder of the secretory epithelium was composed of principal secretory cells which differentiated into partially specialized and fully specialized secretory cells Fig.(15).

\section{5- Ultrastructural studies}

In the present work, the ultrastructural aspects of the peripheral, partially and fully specialized cells of the secretory tubules of the different studied groups were investigated. The peripheral secretory cells contained relatively few small rounded mitochondria and had nearly smooth cell surfaces in comparison to the principal ones for all the selected studied species. However, the peripheral secretory epithelium of un-stressed control birds had relatively few ribosomes and small rounded mitochondria in comparison to those of salt-stressed and wild ducks Fig. (16). The partially specialized cells represented the developmental transition stage to the fully specialized secretory cells in the tubular epithelium Fig. (17). The fully specialized cells become the dominant in the salt gland of the saltstressed and wild migratory ducks. However, the partially specialized cells were the most common ones in the control ducks. The fully specialized cells were located in contact to blood capillaries Fig. (18).

The basal and lateral surfaces of the fully specialized secretory cell type in the saltstressed and wild birds were obviously amplified and in many cases the folds of adjacent cells meshed with one another forming an elaborate complex of extracellular spaces and intracellular compartments Fig.(19). The basal folds generally invested the cytoplasm to the level of the nucleus and, in conjunction with lateral folds, vastly increase the total absorptive surface of the secretory cell 
Fig.(20), this was due to the development of numerous basal infoldings and lateral interdigitations.

The cytoplasm of the well developed fully specialized principal cells which comprise the bulk of the salt gland epithelium of salt-stressed and wild migratory ducks showed abundant free ribosomes and seemed to be a labyrinth of well-developed mitochodria with closely packed cristae in comparison to the control group Fig. (21).

\section{Discussion}

In the present study, the mean weights of the medial segments of the salt glands of the salt-stressed group was obviously heavier than those of the control ones. The same results are obtained from the study of Hossler \& Olson (24) who found that osmotic loading (feeding $1 \% \mathrm{NaCl}$ ) for 1 day and 4 days resulted in increment in the vascular volume of the duckling gland five fold and nine fold respectively, a response that precedes and exceeds that of the gland weight.

In addition, the present findings are parallel with the observations of Bennett \&Hughes (25) who mentioned that the salt glands of many species of ducks hypertrophy when they switch seasonally from fresh water to saline habitat.

Further support for the current observations comes from the study of Rubega \& Oring (26) and Woodin et al. (27) who reported that the mean mass of the salt glands of redheads (Aythya americana) and other waterfowl species are significantly varied depending on the salinity conditions of the environment. They related salt gland size and its efficiency to the salinity regimes experienced by these species.

The increment in the weight of the salt glands in ducks receiving salt water may result entirely from hypertrophy of the secretory cells which is brought about by changes in secretory cell volume and cell number as has been mentioned by Hossler and Hanwell \&Peaker $(11,28)$.

In the present investigation, the observed reddish colour of the salt gland of the saltstressed as well as wild ducks comparing to the control ones are in agreement with the findings of El Gohary (4) on domestic geese. Such result may be attributed to the changes in blood flow to and within the gland as has been recorded by Hossler (11). Confirmation of such observation comes from the study of Hossler \& Olson (24) who found that osmotic loading (feeding $1 \% \mathrm{NaCl}$ ) resulted in increment in the vascular volume of the duckling gland.

In the current work, all the different examined groups have bilateral paired crescent-shaped organ lie within the eye socket beneath the orbital membrane, composed of separate medial and lateral segments. Each medial segment consists of many concentric polygonal lobules arranged in rows and separated by vascularized interlobular connective tissue. Each lobule is made of a mass of parenchymal branched secretory tubules radiate out from a central canal and enmeshed in one cell layer of blood capillaries. The secretory tubules are closely packed and arranged parallel to each other. They are lined by a single layer of principal columnar cells surrounding a narrow lumen while the peripheral blind end of the tubules are lined with short columnar and round basal peripheral cells. The observed histological organizations of the salt glands are in agreement with the results of Almansour (29) and Ahmed (30). They showed that the salt gland in different avian species is a bilateral paired crescent-shaped organ, composed of separate medial and lateral segments. Each segment consists of several longitudinal lobules composed of secretory tubules radiating from central canals.

Several studies correlated the efficiency of the salt gland with its size, the number and length of secretory tubules (2). In the present investigation, the greater number and larger diameter of secretory lobules as well as the longer secretory tubules of the stressed group compared to the control one were recorded. Such findings may reflect high functional efficiency of the gland of the salt-stressed group. The elongation of the secretory tubules may be due to cell proliferation, especially of the peripheral 
cells that line the blind ends of the secretory tubules.

From the structural point of view, the strictly parallel arrangement of closely packed, glandular secretory tubules may be necessary for the osmotic work performed by the gland. It is probable that the manner of distribution of the blood capillaries within the gland tissue is also of importance in this respect (31).

Factors controlling adaptive hypertrophy, which occurs when marine, or potentially marine, birds drink salt water, have been investigated in geese and ducks using changes in salt gland weight, RNA and DNA contents as indices of this process (28). Cells in the salt gland of the domestic ducklings and geese can be induced in vivo to proliferate (11) and to differentiate $(4,32)$ simply by replacement of the animal's drinking water with a $1 \%$ $\mathrm{NaCl}$ solution.

The observed hypertrophy and well-developed basal infoldings and lateral interdigitations of the fully specialized secretory cells of the salt glands of saltstressed ducks are in accordance with the study of Sarras et al. (33). They mentioned that feeding ducklings $1 \%$ sodium chloride (salt stress) induces the secretory cells of the gland to synthesize large amounts of plasma membrane (PM), which forms an extensive basolateral PM domain after 7-9 days of treatment.

In addition, the present findings are in agreement with the results of El Gohary (4) who recorded an obviously increment of the total surface area of the plasma membrane of the fully specialized secretory cells of osmotically stressed geese due to the development of numerous basal infoldings and lateral interdigitations.

Further confirmation of the present observations comes from the study of Müller \& Hildebrandt (34) on ducklings. They reported that when newly hatching ducklings, Anas platyrhynchos, which have never been exposed to excess salt become initially osmotically stressed, the nasal glands start to secrete a moderately hypertonic sodium chloride solution. The number of cells per gland is elevated by a factor of 2-3, the secretory cells differentiate and acquire full secretory capacity. During this differentiation process, extensive surface specializations are formed. The number of mitochondria is increased and metabolic enzymes and transporters are upregulated.

Conclusion: The recorded adaptive growth and differentiation processes may result in a much higher efficiency of salt secretion of the salt gland in salt-stressed ducks to maintain water and electrolyte balance of the body fluid regardless the high salt manipulation.

\section{References:}

1- Laverty G, Skadhauge E (2008). Adaptive strategies for post-renal handling of urine in birds. Comp. Biochem. Physiol., 149: 246-254. 2- Jarrar BM (2009). Microanatomy and histichemistry of the salt glands of the Kentish Plover, Charadrius alexandrines (Aves, Charadiidae). J. Biolo. Sci., 9:75-80.

3- Sabat $\mathbf{P}(\mathbf{2 0 0 0})$. Birds in marine and saline environments : living in dry habitats. Rev. Chil. Hist. Nat., 73: 401-410.

4- El Gohary ZMA (2009). Anatomica 1 and functional alterations of the goose salt gland subjected to sodium chloride. J. Egypt. Ger. Soc. Zool., 58:65-78.

5- Butler DG, Youson JH, Amplion E (1991). Configuration of the medial and lateral segments of duck (Anas platyrhynchos) salt glands. J. Morphol., 207 :201-210.

6- Sturkie PD (1976). Kidneys, extrarenal salt excretion, and urine. In: "Avian Physiology" Springer-Verlag, New York, 264285.

7- Butler DG (2002). Hypertonic fluids are secreted by medial and lateral segments in duck (Anas platyrhynchos) nasal salt glands. J. Physiol., 540:1039-1046.

8- Holmes WN, Phillips JG (1985). The avian salt gland. Biol. Rev., 60: 213-256.

9- Cornelius, S. E. (1982). Wetland salinity and salt gland size in the redhead Aythya americana. Auk, 99: 774-778.

10- Cramp RL, Meyer EA, Sparks N.,Franklin CE (2008). Functional and morphological plasticity of crocodile (Crocodylus porosus) salt glands. J. Exp. Biol., 211: 1482-1489.

11- Hossler FE (1982). On the mechanism of plasma membrane turnover in the salt gland of ducklings. Cell Tissue Res., 226: 531-540.

12- Hildebrandt JP, Gerstberger R, Schwarz M (1998). In vivo and in vitro induction of c-fos in avian exocrine salt gland cells. Am. J. Physiol., 275: 951-957.

\section{3- Hammons RL, Hughes MR,}


Moldenhauer RR (1988). Body water and water flux in fresh water and sea water acclimated Clapper Rails, Rallus longirostris. Comp. Biochem. Physiol., 91: 539-541.

14- Bokenes L, Mercer JB (1997). A morphometric study of the salt gland in freshwater- and saltwater-adapted eider ducks (Somateria mollissima). J. Exp. Zool., 280: 395-402.

15- El Gohary ZMA, El-Sayad FI, Ramadan MM (2009). Comparative studies on the structural organization of the salt glands of two different avian species. Egypt. J. Zool., 53: $18-22$.

16- Hildebrandt JP (2002). Coping with excess salt :adaptive functions of extrarenal osmoregulatory organs in vertebrate. Zool., 104: 209-220.

17- Dunson WA, Dunson MK, Ohmart RD (1976). Evidence for the presence of nasal salt glands in the roadrunner and the coturnix quail. J. Exp. Zool., 198: 209-216.

18- Accordi IA, Barcellos A (2006). Bird composition and conservation in eight wetlands of the hidrographic basin of Guaíba lake, State of Rio Grande do Sul, Brazil. Revista Brasileira de Ornitologia, 14: 101-115.

19 Gooders J, Boyer T (1986). Ducks of North America and the Northern Hemisphere. New York, N.Y.: Dragon's World.

20- arleton T (1980). Carleton's histological technique, fifth edition revised and rewritten by: R.A.B. Drury and E.A. Wallington.

21-Barrett JM, Kriz W, Kaissling B, De Rouffignac C (1978). The ultrastructure of the nephrons of the desert rodent (Psammomys obesus) kidney.Am. J. Anat., 151: 487-498.

22- Watson ML (1958). Staining of tissue sections for electronmicroscopy with heavy metals. J. Anat., 142: 129-139.

23- Reynolds ES (1963). The use of lead citrate at high $\mathrm{pH}$ as an electron-opaque stain in electron microscopy. J. Cell Biol., 17: 208.

24- Hossler FE, Olson KR (1990). Microvascularization of the nasal salt of the duckling, Anas platyrhynchos: quantitative responses to osmotic adaptation and deadaptation studied with vascular corrosion casting. J. Exp. Zool., 254: 237-247.

25- Bennett DC, Hughes RM ( 2003). Comparison of renal and salt gland function in three species of wild ducks. J. Exp. Biol., 206: 3273-3284.

26- Rubega MA, Oring LW (2004). Excretory organ growth and implications for salt tolerance in hatchling American avocets Recurvirostra americana. J. Avian Biol., 35: 13-15.

27- Woodin MC,Michot TC, Lee MC (2008). Salt gland development in migratory redheads (Aythya amereicana) in saline environments on the range, Gulf of Mexico, USA. Acta. Zool. Acad. Sci., 54: 251-264.

28- Hanwell A, Peaker M (1975). The control of adaptive hypertrophy in the salt glands of geese and ducks. J. Physiol., 248: 193-205.

29- Almansour MI (2007). Anatomy, histology and histochemistry of the salt glands of the greater flamingo Phoenicopterus rubber roseus (Aves,Phoenicopteridae). Saudi J. Biol. Sci., 14: 137-144.

30- Ahmed MA (2012). Comparative morphometric study of salt gland in some demosticated and wild marine birds. Bas. J. Vet. Res., 11: 349-354.

31- Newbound DR, O'shea JE (2001). The microanatomy of the rectal salt gland of the Port Jackson shark, Heterodontus portusjacksoni (Meyer) (Heterodontidae): Suggestions for a counter-current exchange system. Cell. Tiss. Org., 162: 165-175.

32- Hildebrandt JP (1997) . Changes in $\mathrm{Na}+/ \mathrm{K}+$-ATPase expression during adaptive cell differentiation in avian nasal salt gland. $\mathbf{J}$ .Exp. Biol., 200:1895-1904.

33- Sarras MP, Rosenzweig LJ, Addis JS, Hossler FE (1985). Plasma membrane biogenesis in the avian salt gland: A biochemical and quantitative electron microscopic autoradiographic study. Am. J. Anat., 174: 45-60.

34- Müller C, Hildebrandt JP (2003). Salt glands - the perfect way to get rid of too much sodium chloride. Biologist, 50: 255 -258. 
Table (1) : Absolute (A.W.S.G.) and relative (R.W.S.G.) weights of the medial segments of the right $(\mathbf{R})$ and left $(\mathrm{L})$ salt glands, number, diameter $(\mu \mathrm{m})$ of secretory lobules and length $(\mu \mathrm{m})$ of the secretory tubules of the control, salt-stressed female domestic ducks (Anas platyrhyncha) and the wild migratory female ducks (Anas clypeata). All the data are represented as means \pm standard errors. Numbers in parentheses are the numbers of the experimental birds.

\begin{tabular}{|c|c|c|c|c|c|c|c|}
\hline \multirow[b]{2}{*}{$\begin{array}{l}\text { Experimental } \\
\text { birds }\end{array}$} & \multicolumn{2}{|c|}{ A.W.S.G.(g) } & \multicolumn{2}{|c|}{ R.W.S.G } & \multirow{2}{*}{$\begin{array}{l}\text { No of } \\
\text { secretor } \\
y \\
\text { lobules }\end{array}$} & \multirow{2}{*}{$\begin{array}{l}\text { Diamete } \\
r \text { of } \\
\text { secretory } \\
\text { lobules } \\
(\mu \mathrm{m})\end{array}$} & \multirow{2}{*}{$\begin{array}{l}\begin{array}{l}\text { Length } \\
\text { of }\end{array} \\
\text { secretor } \\
\text { y tubules } \\
(\mu \mathrm{m})\end{array}$} \\
\hline & $\mathbf{R}$ & $\mathbf{L}$ & $\mathbf{R}$ & $\mathbf{L}$ & & & \\
\hline $\begin{array}{l}\text { a) Control } \\
\text { domestic } \\
\text { ducks (9) }\end{array}$ & $\begin{array}{l}0.39 \pm \\
0.01\end{array}$ & $\begin{array}{l}0.43 \pm \\
0.01\end{array}$ & $\begin{array}{l}0.15 \pm \\
0.01\end{array}$ & $\begin{array}{l}0.16 \pm \\
0.01\end{array}$ & $3 \pm 0.3$ & $772 \pm 55$ & $143 \pm 9$ \\
\hline $\begin{array}{l}\text { b) Salt- } \\
\text { stressed } \\
\text { domestic } \\
\text { ducks (9) }\end{array}$ & $\begin{array}{l}0.57 \pm \\
0.04\end{array}$ & $\begin{array}{l}0.57 \pm \\
0.03\end{array}$ & $\begin{array}{l}0.19 \pm \\
0.02\end{array}$ & $\begin{array}{l}0.19 \pm \\
0.01\end{array}$ & $4 \pm 0.3$ & $1160 \pm 56$ & $157 \pm 9$ \\
\hline $\begin{array}{l}\text { c) Wild ducks } \\
\text { (9) }\end{array}$ & $\begin{array}{l}0.14 \pm \\
0.02\end{array}$ & $\begin{array}{l}0.15 \pm \\
0.02\end{array}$ & $\begin{array}{l}0.12 \pm \\
0.02\end{array}$ & $\begin{array}{l}0.12 \pm \\
0.02\end{array}$ & $4 \pm 0.3$ & $913 \pm 58$ & $155 \pm 15$ \\
\hline $\begin{array}{l}\text { Probabilit } \\
\text { y } \\
\text { a vs b }\end{array}$ & $\begin{array}{l}\mathbf{P}<0.00 \\
1 \\
(\mathbf{S})\end{array}$ & $\begin{array}{l}\text { P<0.00 } \\
1 \\
\text { (S) }\end{array}$ & $\begin{array}{l}\mathbf{P}<0.0 \\
\mathbf{5} \\
(\mathbf{S})\end{array}$ & $\begin{array}{l}\text { P>0.0 } \\
5 \\
(\mathrm{NS})\end{array}$ & $\begin{array}{l}\mathbf{P}<\mathbf{0 . 0 1} \\
(\mathbf{S})\end{array}$ & $\begin{array}{l}\text { P<0.001 } \\
(\mathrm{S})\end{array}$ & $\begin{array}{l}p>0.05 \\
\text { (NS) }\end{array}$ \\
\hline a vs c & $\begin{array}{l}\mathbf{P}<0.00 \\
1 \\
(\mathrm{~S})\end{array}$ & $\begin{array}{l}\text { P<0.00 } \\
1 \\
(\mathbf{S})\end{array}$ & $\begin{array}{l}\mathbf{P}<0.0 \\
5 \\
(\mathrm{~S}) \\
\end{array}$ & $\begin{array}{l}\text { P>0.0 } \\
5 \\
(\text { NS) }\end{array}$ & $\begin{array}{l}\mathbf{P}<0.05 \\
\text { (S) }\end{array}$ & $\begin{array}{l}\mathbf{P}<0.05 \\
\text { (S) }\end{array}$ & $\begin{array}{l}\text { P>0.05 } \\
\text { (NS) }\end{array}$ \\
\hline b vs c & $\begin{array}{l}<<0.00 \\
1 \\
(S)\end{array}$ & $\begin{array}{l}\text { P<0.00 } \\
1 \\
\text { (S) }\end{array}$ & $\begin{array}{l}\mathbf{P}<0.0 \\
5 \\
(\mathbf{S})\end{array}$ & $\begin{array}{l}\text { P>0.0 } \\
5 \\
(\mathrm{NS})\end{array}$ & $\begin{array}{l}p>0.05 \\
\text { (NS) }\end{array}$ & $\begin{array}{l}\text { P<0.01 } \\
(\mathbf{S})\end{array}$ & $\begin{array}{l}p>0.05 \\
\text { (NS) }\end{array}$ \\
\hline
\end{tabular}

S= Significant.

NS = Non-significant

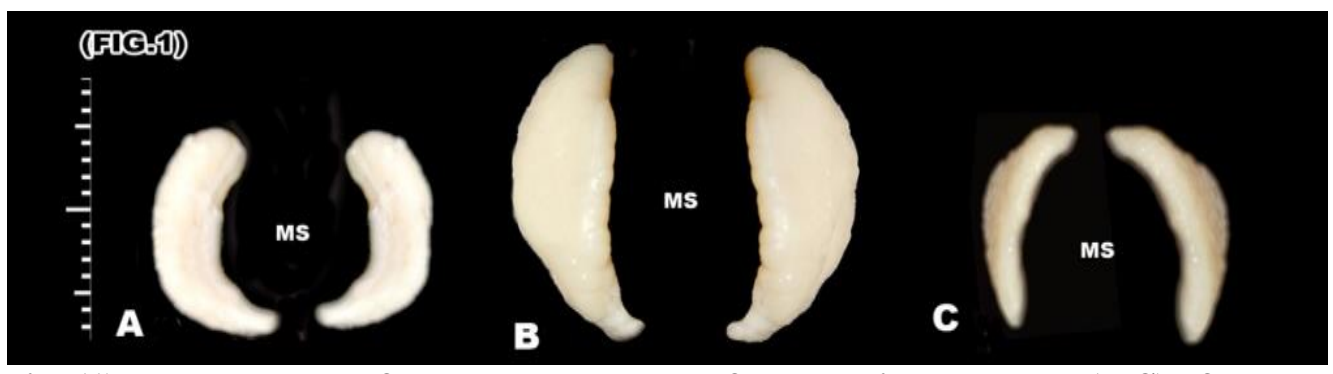

Fig. (1): Photographs of the gross anatomy of the medial segments (MS) of the salt glands of the control (A) and salt-stressed (B) domestic ducks as well as wild migratory duck $(\mathrm{C})$. Note the relatively dark reddish colour and the large size of the salt gland of the salt-stressed duck compared to the control one. ( $X$ 20) 


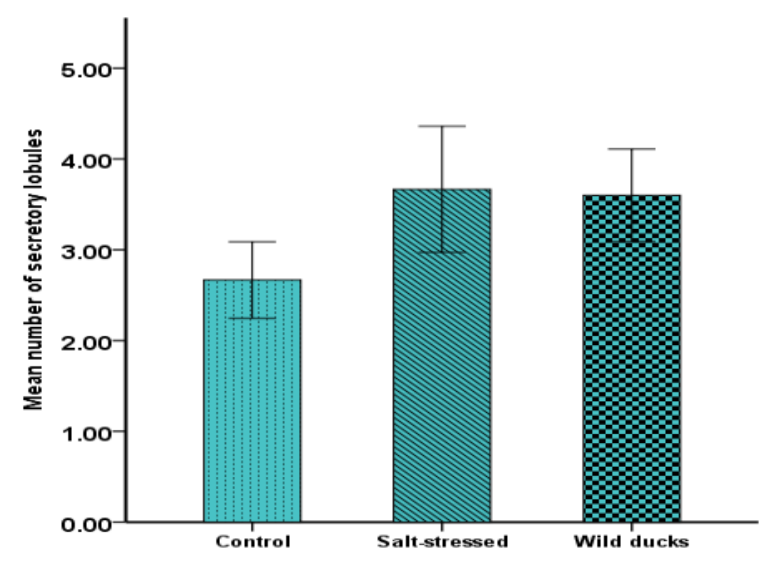

Fig. (2): Number of secretory lobules of the control, salt-stressed female domestic ducks (Anas platyrhyncha) and the wild migratory female ducks (Anas clypeata). $\{$ bars $=\mathrm{SE}\}$

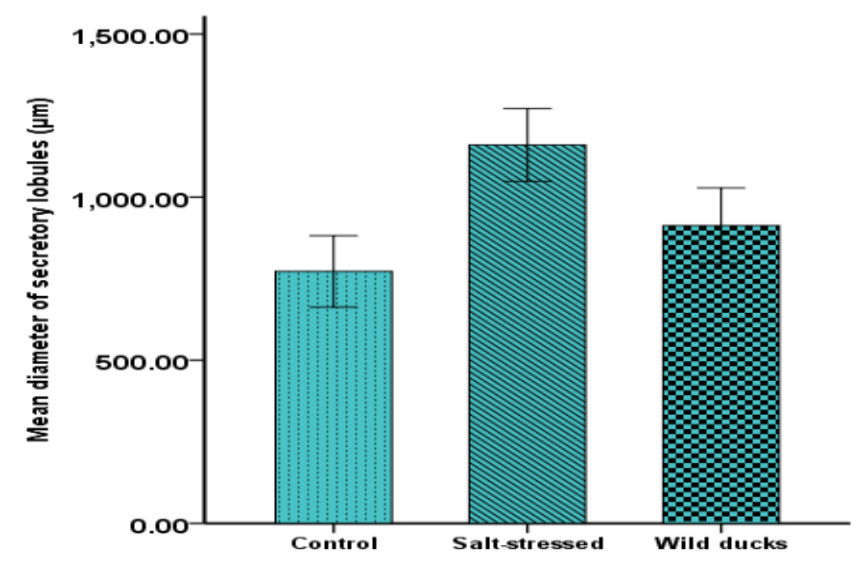

Fig. (3): Diameter of secretory lobules $(\mu \mathrm{m})$ of the control, salt-stressed female domestic ducks (Anas platyrhyncha) and the wild migratory female ducks (Anas clypeata $).\{$ bars $=\mathrm{SE}\}$

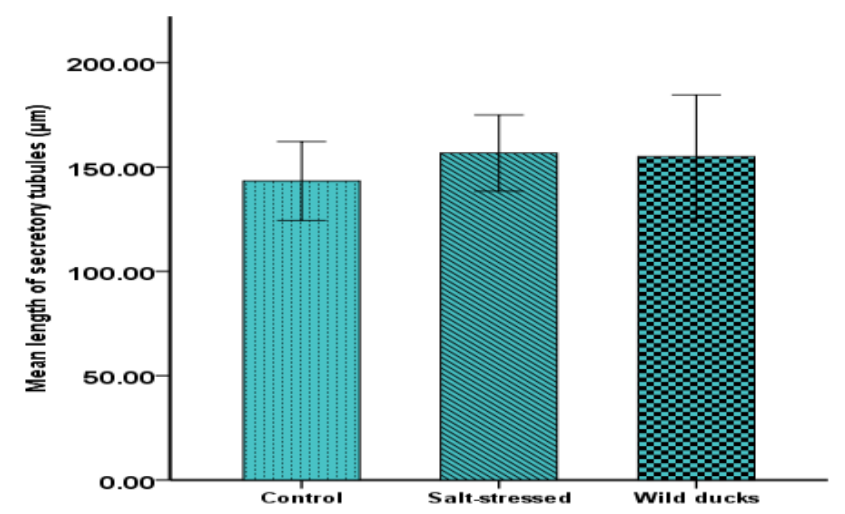

Fig. (4): Length of secretory tubules $(\mu \mathrm{m})$ of the control, salt-stressed female domestic ducks (Anas platyrhyncha) and the wild migratory female ducks (Anas clypeata $).\{$ bars $=\mathrm{SE}\}$ 


\section{(ज्ञल(D)}

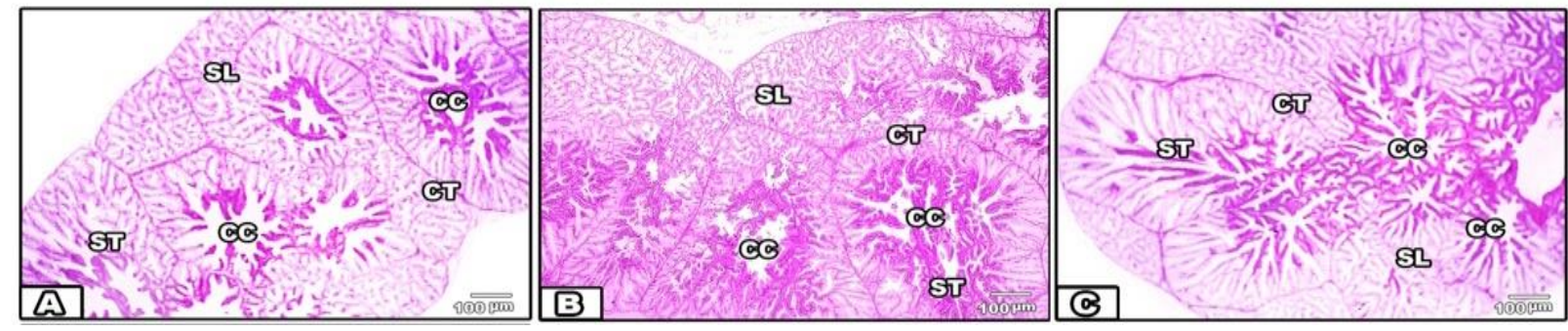

Fig. (5): Photomicrographs of transverse sections in the medial segments of the salt glands of the control (A) and salt-stressed (B) domestic ducks as well as wild migratory duck (C) showing the secretory lobules (SL), the secretory tubules (ST), the central canal (cc), the interlobular connective tissue (CT). Note that the secretory lobules of the salt-stressed and wild ducks are larger than those of the control. (H\&E, X 40).

(झ००)

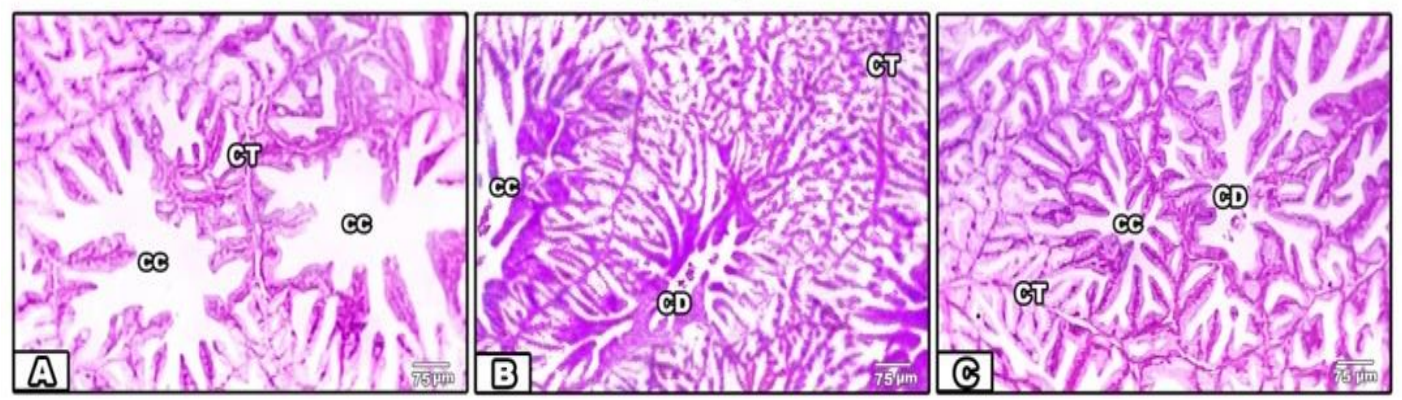

Fig.(6): Photomicrographs of transverse sections in the medial segments of the salt glands of the control (A) and salt-stressed (B) domestic ducks as well as wild migratory duck (C) showing an enlarged secretory lobule with central canal (CC) containing cellular debris $(\mathrm{CD})$ resulting from high proliferation of the secretory cells along the secretory tubule of the salt-stressed duck.(H\&E, X 100).

(FGDT)
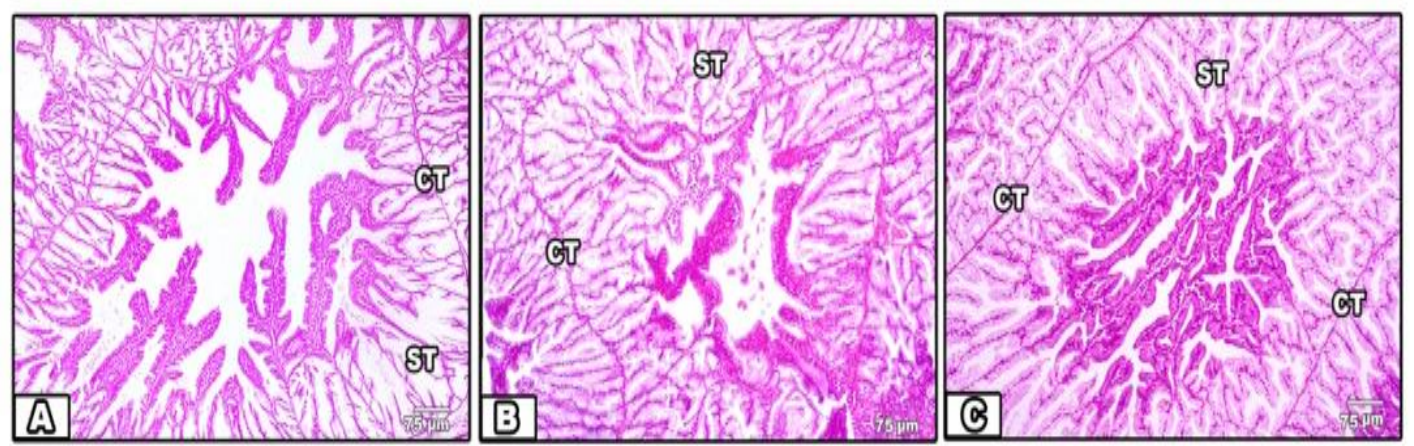

Fig.(7): Photomicrographs of transverse sections in the medial segments of the salt glands of the control (A) and salt-stressed (B) domestic ducks as well as wild migratory duck (C) showing the secretory tubules (ST) run parallel to each other, separated by very delicate connective tissue membranes $(\mathrm{CT})$. The tubules are closely packed together in both salt-stressed and wild ducks. (H\&E, X 120). 

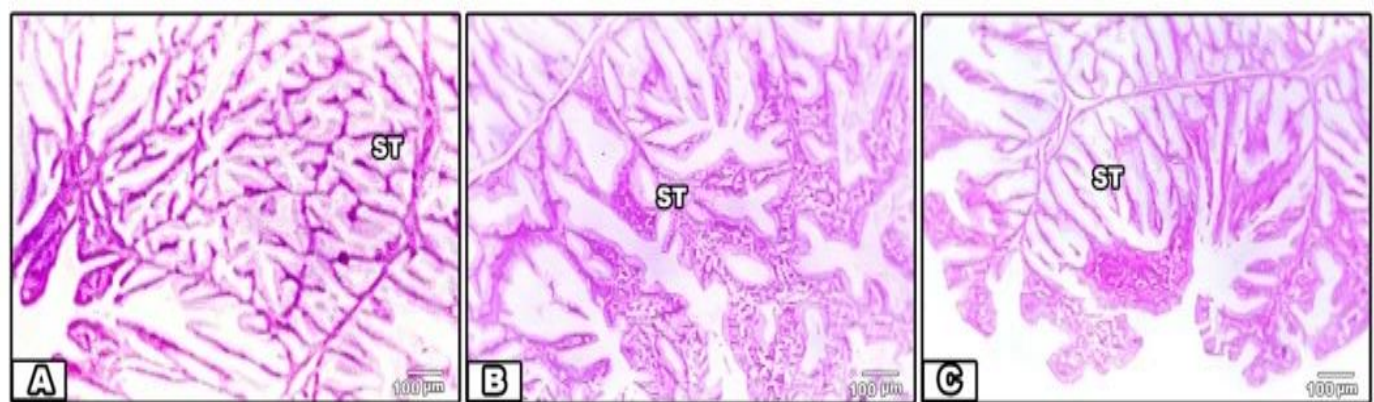

Fig. (8): Photomicrographs of transverse sections in the medial segments of the salt glands of the control (A) and salt-stressed (B) domestic ducks as well as wild migratory duck (C) showing the secretory tubules (ST) branched forming many generations in which the degree of the hypertrophy of the branched secretory tubules is greater in saltstressed than both control and wild ducks.(H\&E, X250).

(जस्थ)

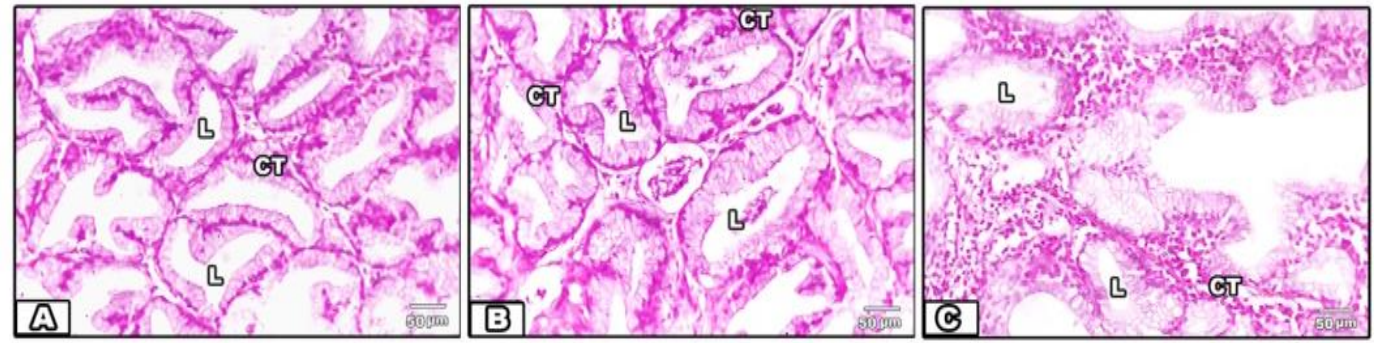

Fig. (9): Photomicrographs of transverse sections in the medial segments of the salt glands of the control (A) and salt-stressed (B) domestic ducks as well as wild migratory duck (C) showing the tubules are round in transverse section with lumen (L).(H\&E, X350).

\section{(IFT)10)}
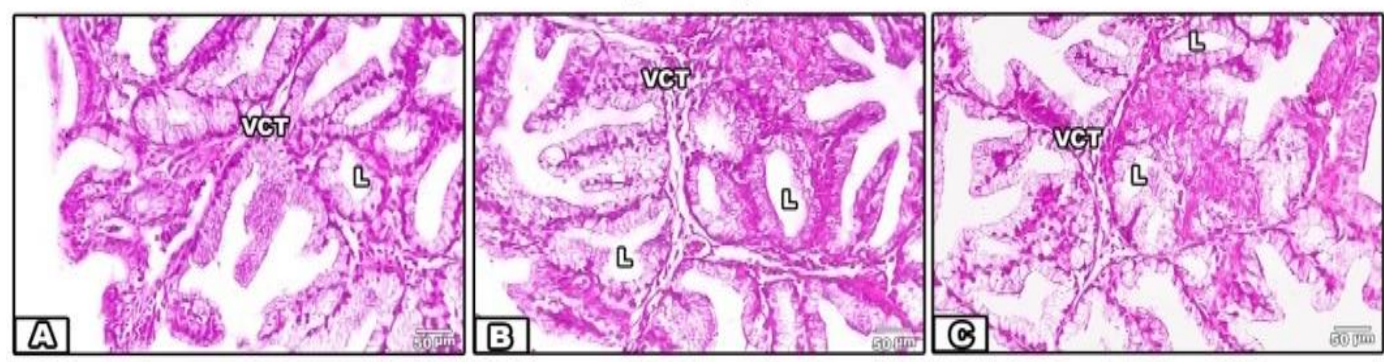

Fig.(10): Photomicrographs of transverse sections in the medial segments of the salt glands of the control (A) and salt-stressed (B) domestic ducks as well as wild migratory duck (C) showing the secretory tubules separated by highly vascularised connective tissue (VCT) in salt-stressed and wild ducks compared to control ones. (H\&E, X350).

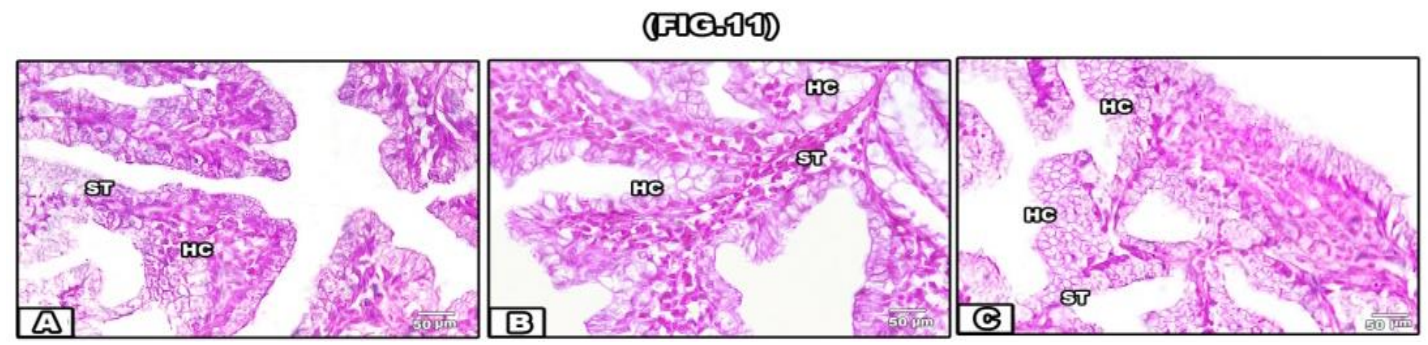

Fig. (11): Photomicrographs of transverse sections in the medial segments of the salt glands of the control (A) and salt-stressed (B) domestic ducks as well as wild migratory 
duck (C) showing the secretory tubules formed a honeycomb-like pattern at the peripheral parts of a lobule. (H\&E, X 450).

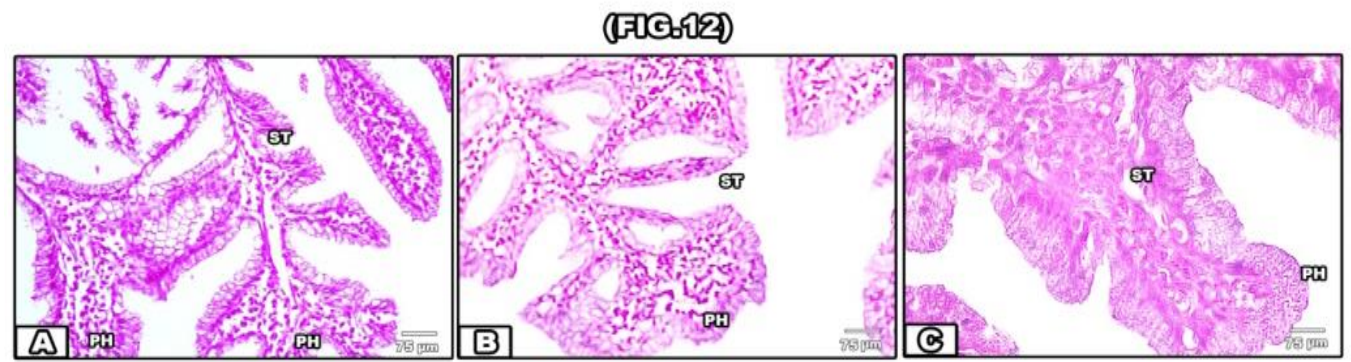

Fig. (12): Photomicrographs of transverse sections in the medial segments of the salt glands of the control (A) and salt-stressed (B) domestic ducks as well as wild migratory duck $(C)$ showing the cytoplasm of the cells had a lamellate or striate appearance. (H\&E, X 400).

(ำลปร)

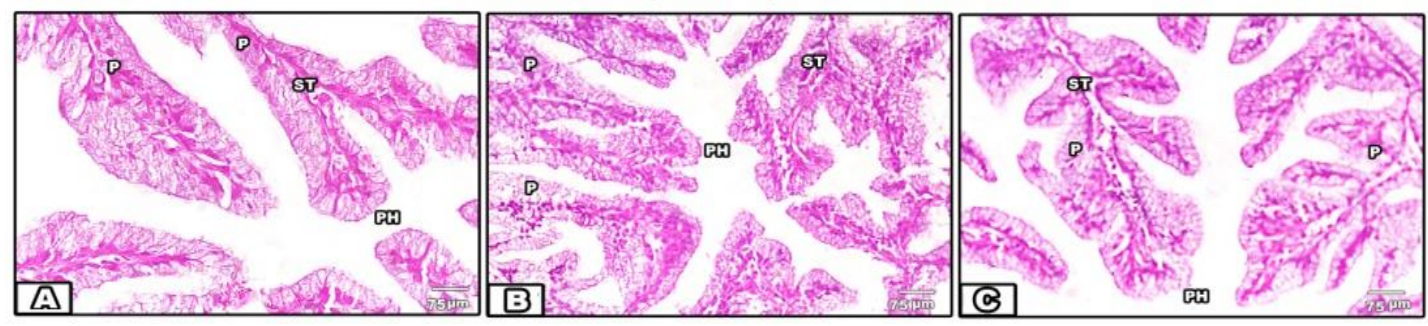

Fig. (13): Photomicrographs of transverse sections in the medial segments of the salt glands of the control (A) and salt-stressed (B) domestic ducks as well as wild migratory duck (C) showing the secretory tubules (ST) are lined by peripheral cells (PH) and principle secretory cells $(\mathrm{P})$. (H\&E, X250).

(F)

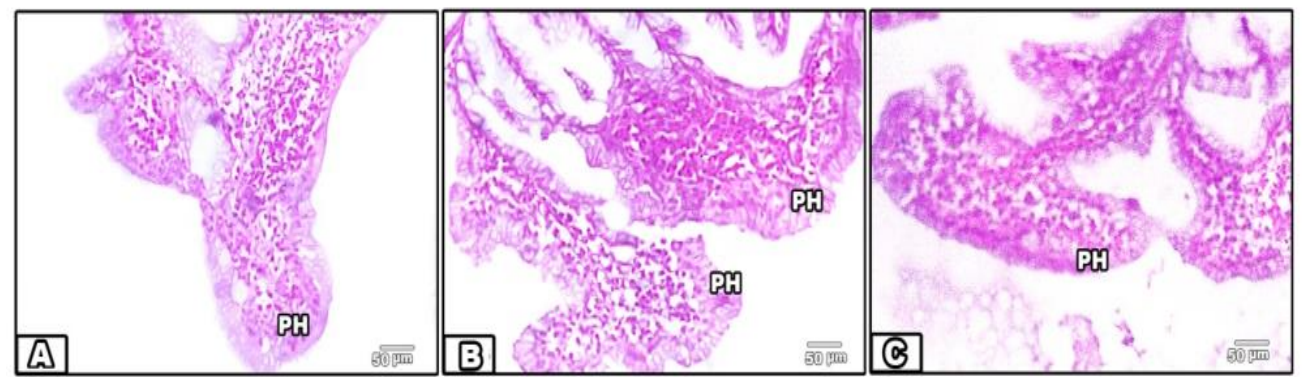

Fig. (14): Photomicrographs of transverse sections in the medial segments of the salt glands of the control (A) and salt-stressed (B) domestic ducks as well as wild migratory duck (C) showing the cellular proliferation of the peripheral cells $(\mathrm{PH})$, the degree of which is distinctly greater in salt-stressed ducks than both the wild migratory and the control ducks. (H\&E, X 500).

(जबลป5)

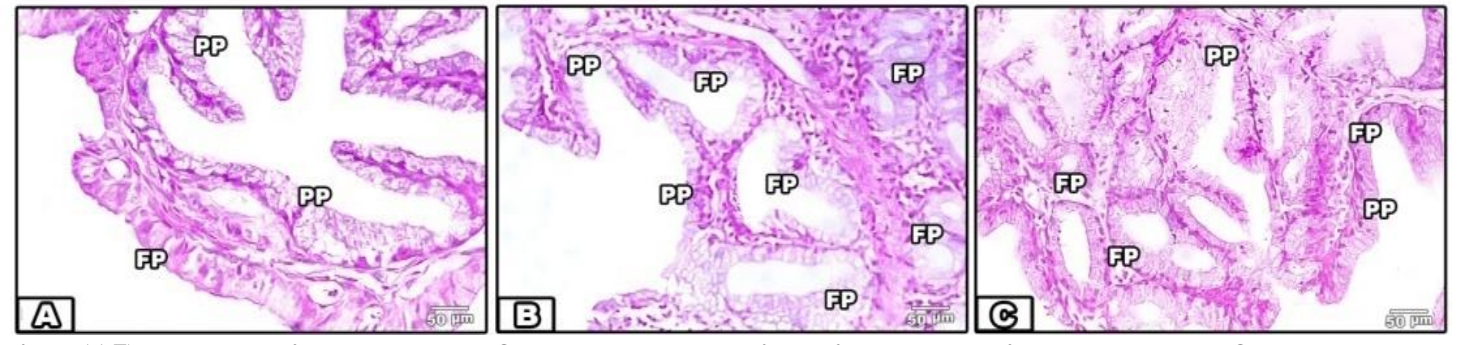

Fig. (15): Photomicrographs of transverse sections in the medial segments of the salt glands of the control (A) and salt-stressed (B) domestic ducks as well as wild migratory 
duck (C) showing the principal secretory cells differentiated into partially specialized (PP) and fully specialized (FP) cells.(H\&E, X 350).

(Fفㄴ)

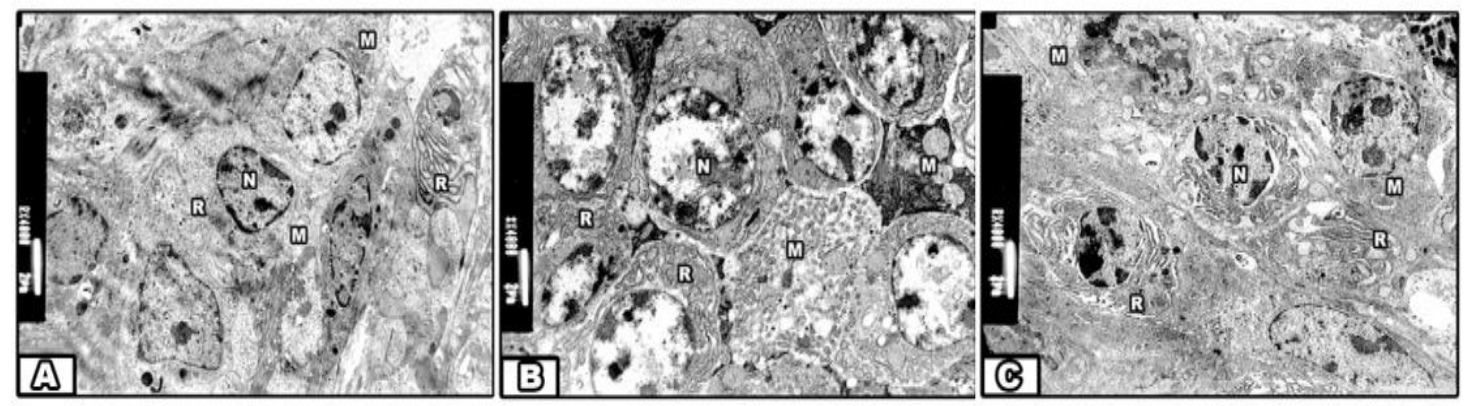

Fig. (16): Transmission electron micrographs at the blind end of the secretory tubules of the control (A) and salt-stressed (B) domestic ducks as well as wild duck (C) showing numerous cells resulting from higher proliferating rate in peripheral cells of the salt-stressed and wild ducks. The cells have spherical centrally located nuclei $(\mathrm{N})$, endoplasmic reticulum (R) and small rounded mitochondria (M).

(झबढত)

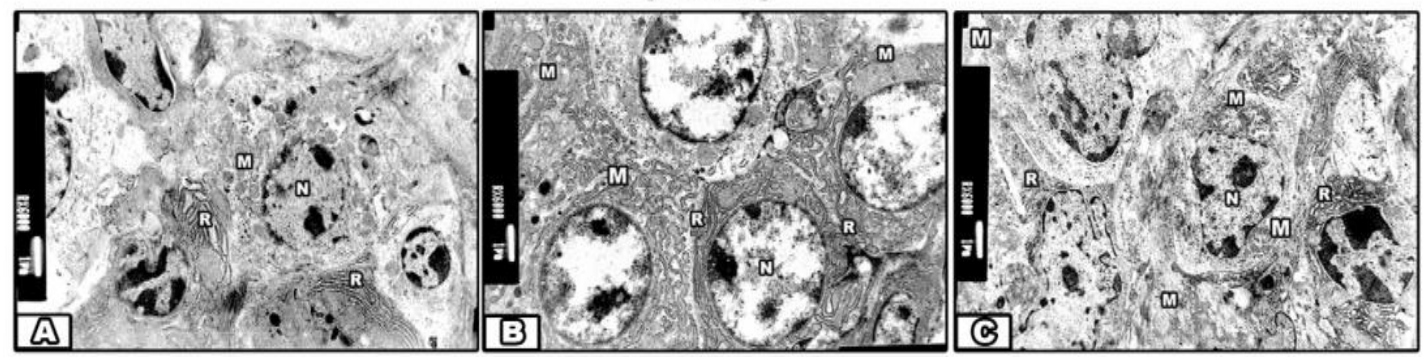

Fig. (17): Transmission electron micrographs of the partial specialized secretory cells of the control (A) and salt-stressed (B) domestic ducks as well as wild duck (C) showing endoplasmic reticulum and numerous rounded mitochondria $(M)$ characteristic to the cells of the salt-stressed and wild ducks.

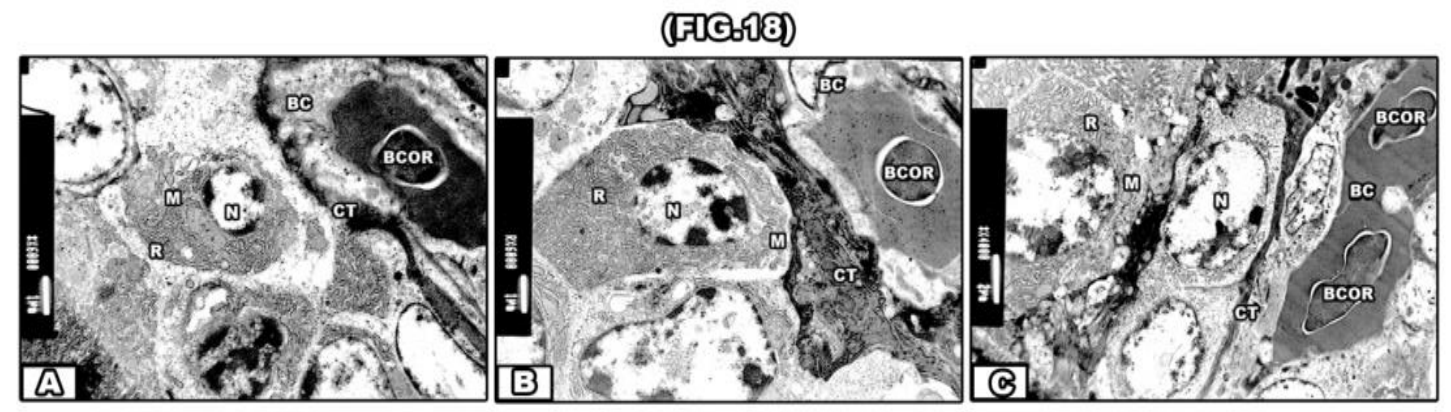

Fig. (18): Transmission electron micrographs of the fully specialized secretory cells of the control (A) and salt-stressed (B) domestic ducks as well as wild duck (C) showing distinct rounded nucleus $(\mathrm{N})$, numerous mitochondria $(\mathrm{M})$. The cells located in contact to blood capillaries (BC) containing blood corpuscles (BCOR). 


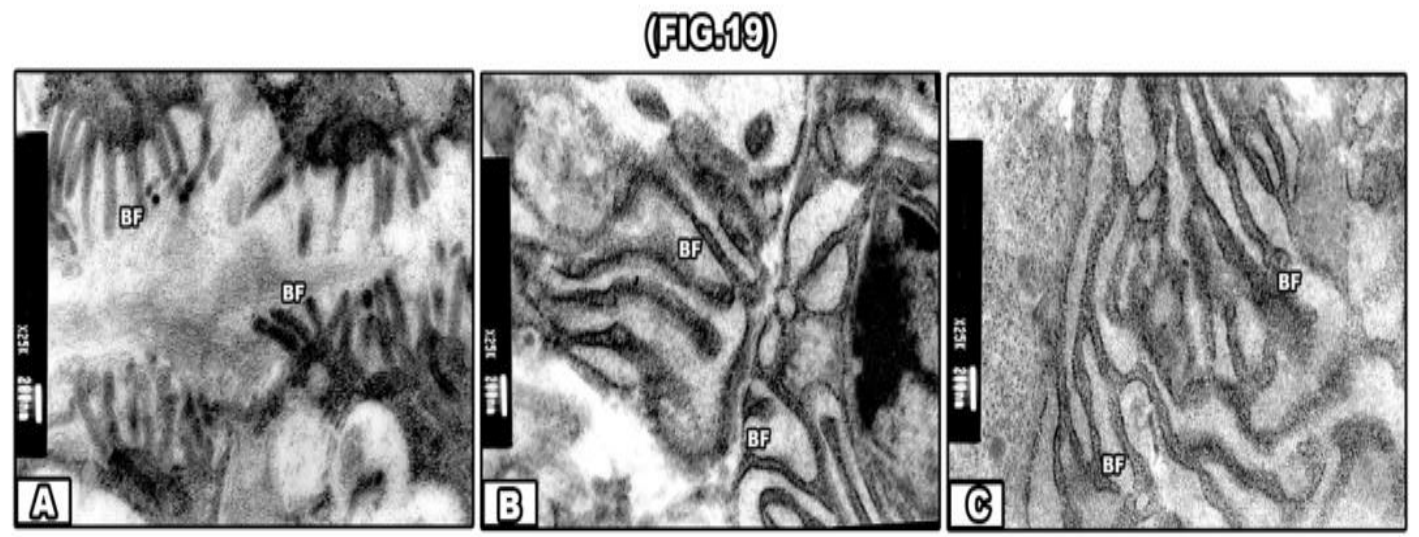

Fig. (19): Transmission electron micrographs of the fully specialized secretory cells of the control (A) and salt-stressed (B) domestic ducks as well as wild duck (C) showing the basal and lateral surfaces in the salt-stressed and wild birds are obviously amplified and the basal folds (BF) of adjacent cells meshed with one another.

(ज्ञस्20)

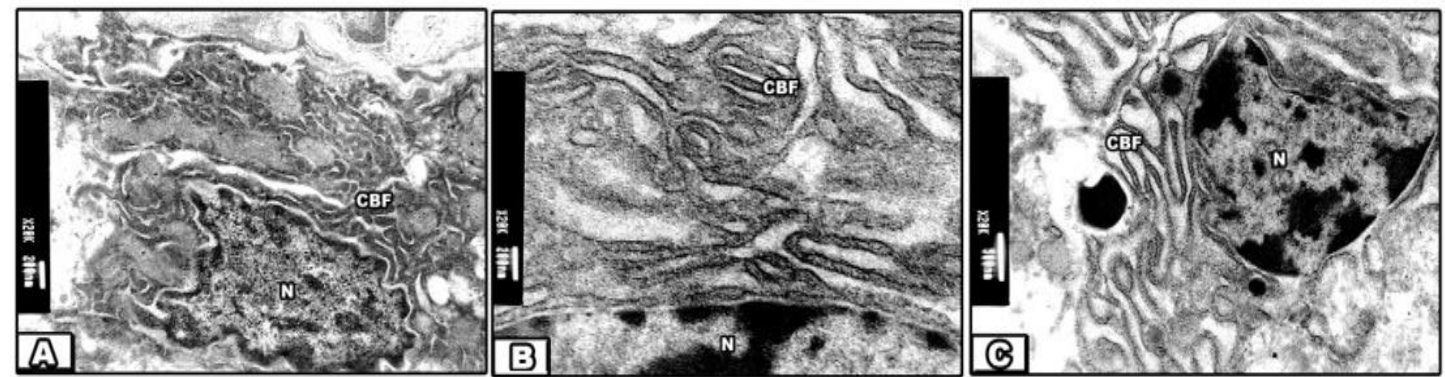

Fig. (20): Transmission electron micrographs of the fully specialized secretory cells of the control (A) and salt-stressed (B) domestic ducks as well as wild duck (C) showing the complex basal folds (CBF) which generally invested the cytoplasm to the level of the nucleus $(\mathbf{N})$.

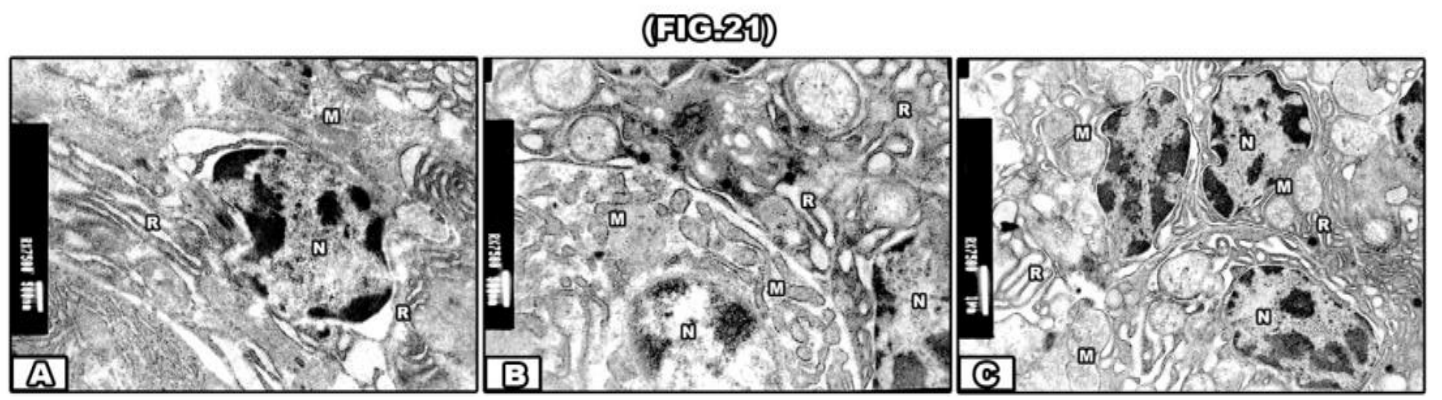

Fig.( 21): Transmission electron micrographs of the fully specialized secretory cells of the control (A) and salt-stressed( B) domestic ducks as well as wild duck (C) showing the cytoplasm of the salt-stressed and wild migratory ducks having abundant endoplasmic reticulum $(R)$ and seemed to be a labyrinth of well-developed mitochondria (M) with closely packed cristae. 